\title{
The Role of Citi-forming Industrial Enterprises in the Development of Innovative and Investment Attractiveness of Russian Regions (on the Example of Stary Oskol, Belgorod Region and the «OEMKINVEST ltd»)
}

\author{
Elena Chizhova \\ Department of the Theory and Science Methodology, Economics \\ and Management Institute \\ Belgorod State Technological University \\ named after V.G. Shukhov \\ Belgorod, Russia \\ chizhova_elena@mail.ru \\ VeraTuaeva \\ Department of Construction Management and Real Estate, \\ Construction Engineering Institute \\ Belgorod State Technological University \\ named after V.G. Shukhov \\ Belgorod, Russia \\ veronichkatuatva@mail.ru
}

\begin{abstract}
The article considers the role of single-industry towns and city-forming enterprises in the formation of the investment attractiveness of the region. It is shown that from an epoch of industrialisation we've got a problem of settlements of the various size having monoindustrial structure. But monocities of the Belgorod region which basic manufacture is the extraction of iron ore, have kept the specialisation and investment appeal. The city of Stary Oskol having singleindustry town enterprise concerns such cities as Oskol electrometallurgical industrial complex. Its role in region development is the main problem of the article. Models of influence of the Oskol electrometallurgical plant as a city-forming enterprise on the socio-economic development of the Belgorod region such as public-private partnership and corporate responsibility are investigated too. These models are equally used by «OEMKINVEST LTD». The special attention is given to the issues of inter-municipal cooperation of Stary Oskol and the nearby located Gubkin (also a monocity) which is represented a territorially-economic complex on extraction and processing of iron ore and domination of «OEMKINVEST LTD». It is considered that «OEMKINVEST LTD» supports the budget of the Belgorod region and makes innovative-investment support to a development of Stary Oskol.
\end{abstract}

Keywords--region, single-industry town, socio-economic development, inter-municipal cooperation, public-private partnership, corporate responsibility, city-forming enterprise, inter-municipal cooperation.

\author{
Irina Rozdolskaya \\ Department of Marketing and Management \\ Belgorod University of Cooperation, \\ Economics \& Law \\ Belgorod, Russia \\ rozdolskaya-irina@mail.ru \\ Sergey Chizhov \\ Department of Economics and Production Organization, \\ Economics and Management Institute Belgorod State \\ Technological University \\ named after V.G. Shukhov \\ Belgorod, Russia \\ chijov@intbel.ru
}

\section{INTRODUCTION}

In Russia, as in other countries of the world, there is a problem of single-industry town (monotown). Singleindustry town is characterized by the systemic unity of its socio-economic organization and the functioning of the cityforming enterprise [1]. Until the present in most Russian regions, large industrial enterprises located on their territory remain the most important source of regional investment potential formation, many of which play the role of cityforming. The definition of a city-forming enterprise: «the functioning of one of the organizations (one of the branches of a legal entity in a municipality or several organizations) that carry out the same type of main economic activity on the territory of a municipality or whose activities are carried out as part of a single production and technological process» [2].

In world practice, some experience has already been gained in solving problems related to the maintenance or development of territories with city-forming enterprises. Certain models, mechanisms, forms of support or conditions of destruction have been developed.

In Russia, the issue with city-forming enterprises theoretically, and practically arose later compared to Europe and the USA due to the peculiarities of its development. The 21 st century forced government bodies to see and turn to city- 
forming enterprises, develop programs, create funds, look for financing opportunities, and sources of investment.

The program for the development of single-industry towns in Russia was launched in 2014. The state has started a number of tools, or more precisely, channels for financing activities for the development of single-industry towns.

1. To solve the problem of single-industry towns, a targeted program «Integrated Development of SingleIndustry Towns» was developed and adopted at the state level. According to the passport of the priority program «Integrated Development of Single-Industry Towns,» the main goal is «to reduce the dependence of single-industry towns on the work of city-forming enterprises. The program is designed until December 2025» [3].

2. The Fund for the Development of Single-Industry Towns, established by Vnesheconombank, was organized. The main task of this Fund is to invest in the formation of new managerial competencies and improve the quality of human capital of the administrative facilities of municipalities. In addition, the Fund should invest in the development of the infrastructure of these territories. This will create favorable conditions for attracting business investors and increase the investment attractiveness of the territory.

The functions of the monotowns Development Fund include monitoring the state of the economy and social sphere of monotowns. A list of single-industry towns of Russia was compiled, divided into three groups according to the level of their socio-economic development. For the Belgorod region, the issue of single-industry towns and city-forming enterprises is relevant.

The key objective of the above-mentioned support measures is to strengthen investment partnership mechanisms.

Belgorod region is a storage of minerals that are mined and processed on an industrial scale, including by cityforming enterprises. The basis for the socio-economic development of the Belgorod region is the industrial complex, in the structure of which the gornometallurgical component, located mainly in the cities of Gubkin and Stary Oskol, has a significant share. The basis for the socioeconomic development of the Belgorod region is the industrial complex, in the structure of which the gornometallurgical component, located mainly in the cities of Gubkin and Stary Oskol, has a significant share. Leading enterprises of the mining and metallurgical complex: AO «Lebedinsky GOK» (Gubkin), AO «KMAruda Combine» (Gubkin) AO «Stoilensky GOK» (Stary Oskol), AO «Oskol Electrometallurgical Plant». According to the methodology of Monocities Development Fund, Gubkin is one of the single-industry towns, Stary Oskol is not. But the Oskol Electrometallurgical Plant (OEMKINVEST LTD) is considered a city-forming enterprise for the second largest city in the Belgorod region - Stary Oskol.

The industrial complex directly depends on the level of infrastructure support, which depends on the size of the investment, investment potential and investment attractiveness of the territory.

The need for investment is almost unlimited, and the money that can be invested is limited. In this regard, investors and business angels carefully evaluate the facilities for financing. However, until the present the role of individual industries, production complexes and individual enterprises in the socio-economic development of the regions remains insufficiently studied.

The purpose of the article is to consider the mechanisms of influence of the city-forming metallurgical enterprise on the socio-economic development of the region.

The tasks arising from the goal: to explore the social possibilities of single-industry towns of the Belgorod region; models of interaction of the city-forming enterprise with the regional and municipal authorities, aimed at the formation of investment attractiveness.

\section{METHODOLOGY}

The authors used general scientific methods of scientific knowledge in their study: analysis, synthesis, induction, abstraction, a system-structural approach, a methodology of institutional and strategic analysis, as well as special methods - comparative-historical and regulatory-legal, were based on the tectological (organizational) methodology of A.A. Bogdanov.

\section{RESULTS AND DISCUSSION}

Monocities Development Fund identified the top ten most successful single-industry towns in Russia, which included the city of Gubkin, Belgorod Region, with an industrial specialization in «iron ore mining and processing». Iron ore continues to be a strategic resource of the country, the need for its production does not decrease, and the mining territory characterizing the quality of ore is the famous Kursk magnetic anomaly. Thus, Gubkin has no «classic» problems as a single-industry town. The single-industry town, located $21 \mathrm{~km}(26 \mathrm{~km}$ along the highway, travel time - 21 minute by car) from Gubkin, Stary Oskol, whose largest enterprise is «OEMKINVEST LTD», which is engaged in the processing of enriched iron ore, also contributes to the reduction of problems. In fact, «OEMKINVEST LTD» is a city-forming enterprise in the city of Stary Oskol, but the city has never been included in the list of single-industry towns, having on its territory smaller enterprises of diversified production. Given the territorial proximity and good transport communication, the cities of Gubkin and Stary Oskol, despite their municipal autonomy, are an industrial agglomeration, which allows, among other factors, the city of Gubkin, which belongs to single-industry towns, to be included in the category of successful. In this case, the «expediency principle» of A. Bogdanov is implemented, when the activity of one subject and the activity of another, uniting, jointly contribute to achieving the goal [4].

Thus, from the point of view of a single-industry town and city-forming enterprises, from the point of view of an industrial mining and metallurgical complex and from the point of view of regional efficiency, the socio-economic development of the cities of Gubkin and Stary Oskol should be considered in unity. After all, any organizational system is based on the system principle «an integer is greater than the sum of its parts» [4] and it is not static [5].

The State Program for the Development of SingleIndustry Towns provided for state support in various forms through the Monocities Development Fund or the mechanism of territories of advanced socio-economic development. On March 30, 2015, Federal Law No. 473-Ф3 entered into force, 
which establishes the legal norm of the territory of advanced socio-economic development [6]. The purpose of the law is the legal provision of comfortable living conditions for a person due to the accelerated development of the economy. The main role here is to play investment, to attract them it is necessary «to create an enabling environment for entrepreneurship through the development of the institutional environment and infrastructure» [6].

In 2018, Gubkin received the status of a territory of advanced socio-economic development, as a result of which appropriate regional and local support measures were taken for organizations - residents of the territory of advanced socio-economic development (preferential differentiated interest rates on income tax and property tax of organizations; exemption from land tax; leasing State or municipal land without bidding; land rental and acquisition benefits; preferential rates of insurance premiums). As of the end of 2019, 20 residents were located on the territory [7].

In the world, there are various models of the influence of city-forming enterprises on the development of regions in the mechanism of their interaction with the state. The most important of them are public-private partnership and corporate responsibility.

Public-Private Partnership - legally formalized for a certain period and based on the pooling of resources, the distribution of risks, cooperation between a public partner, on the one hand, and a private partner, on the other, in order to attract private investment to the economy, ensure the availability of goods, work, services and their quality by state authorities and local authorities.

In the United States, cooperation between government and private business is particularly widespread and welcome at the municipal level [8].

Special attention in the framework of public-private partnerships is paid to social projects, it is believed that one hundred social investments replace the social expenditures of the state. The main forms of interaction are the conclusion of agreements with the administration of cities and regions, the holding of discussions with the participation of representatives of authorities and public organizations.

Various forms of interaction between the state and private business are used (they are also called models):

- a rental model according to which state or municipal property is transferred to a private partner for temporary use and a corresponding fee;

- leasing model, according to which state or municipal property is leased with subsequent right of redemption;

- a concession model whereby the State authorizes a private partner to perform, for a period of time specified in the agreement, functions using State or municipal property;

- contract model, according to which a contract is concluded for the performance of work, supply of products for state needs.

The public-private partnership mechanism, as shown by foreign practice, can be effective under the following conditions:

- economic interest in participation in the project of private companies;
- The legal and regulatory framework governing the relationship of project participants;

- optimization of the mechanism of risk allocation, which determines mutual obligations of the project participants [9].

The regulatory framework was formed by 2015 , when the law «On Public-Private and Municipal-Private Partnerships in the Russian Federation» was adopted.

Risks in a public-private partnership are usually distributed as follows: the state assumes risks associated with a change in legislation, the occurrence of force majeure; private companies are exposed to risks associated with the construction and operation of the facility. Risk allocation affects the interest of a private company. The rule is as follows: the less guarantees from the state, the higher should be the efficiency of the project for a private investor.

Corporate model of regional influence of city-forming enterprises, or corporate responsibility. suggests that the enterprise mainly independently develops the socioeconomic infrastructure of the region, contributes to the development of the main macro, meso- and microeconomic processes.

Corporate responsibility has traditionally been understood in management as caring for employees and helping local governments. Currently, it has changed its content and has become perceived as a management model. Western management theorists gave it the name $« 3 \mathrm{P} »-$ profit, people, planet, understanding by this that the company has equal social responsibility for making profits, caring for workers, caring for the territory in which it is located, caring for the population of the territory. Forms can be varied: the development and implementation, together with the authorities, of long-term social programs; creation of own foundations, support of existing foundations, organization of charity or volunteer events.

According to the Belgorod authorities, the Belgorod region is a region of high opportunities for the implementation of investment innovation and technology projects of any complexity and orientation in the conditions of minimum regional investment risks [10].

Since 2018, a new investor support mechanism has been introduced in the Belgorod Region for the accelerated development of industries - a regional special investment contract (SPIC), under which reduced tax rates on property tax are provided. In 2019, three regional SPICs were concluded, including with «OEMKINVEST LTD» (OOO «RUSAGRO - BELGOROD», AO «OEMKINVEST LTD », AO «Lebedinsky GOK») $[10,11]$.

The investments volume in the fixed capital of the region for 2019 year amounted to 167.4 billion rubles, which in comparable prices is $16.6 \%$ more than the level of 2018 year. The volume of investments in fixed assets without small businesses is 97.5 billion rubles (20.7\% more than in 2018). At the same time, the bulk of investments is aimed at the development of mining (23.7\%), manufacturing (20.8\%) [10].

The dependence of cities on a city-forming enterprise or dominant enterprises is reflected in the share of tax deductions and fees received by the city budget. Large industrial enterprises located in the territory of the 
municipality and operating within the framework of a single production and technological cycle, as a rule, form more than $20 \%$ of the total revenue of the budget from all taxes and fees. So, the mining and metallurgical company «Metalloinvest», which includes «OEMKINVEST LTD», paid 19.6 billion rubles in 2019 to the consolidated budget of the Belgorod region. [11]. This indicates the positive impact of the «financial sustainability» factor on the investment attractiveness of the region.

Resources provided by city-forming enterprises can constitute only the first component of a favorable investment climate necessary for the development of the region. No less important is the second component, which consists in the formation of the investment attractiveness of the region through the reduction of risks that may arise due to the work of one enterprise and its impact on the development of the territory.

In our opinion, the tasks of the development of singleindustry towns are mainly formed within the framework of three areas to reduce risks and create a favorable innovation and investment climate: 1) diversification of the economy; 2) infrastructure development; 3) improving the quality of human capital. These directions are in line with the factors that determine investment attractiveness.

According to the results of the investment attractiveness rating of the Russian regions conducted by the «Expert RA» rating agency in December 2019, the Belgorod region took 2nd place and has a minimum investment risk in the Russian Federation, after the Moscow region. According to the results of the National Rating of the State of the Investment Climate in the Constituent Entities of the Russian Federation, summed up by the Agency for Strategic Initiatives to Promote New Projects at the St. Petersburg International Economic Forum, the Belgorod Region entered the top 10 (8 place) investment attractive regions [10].

A very important indicator of the quality of life of the population, affecting the investment attractiveness of the region, is the average monthly wage.

With an average salary of 34614.5 rubles in the Belgorod region in 2019, the average salary in the city of Gubkin was 40725 rubles, and in Stary Oskol - 40902 rubles. [7], moreover, for mining - 51614.3 rubles, and for metallurgical production - 57567.6 rubles. [7].

«Metalloinvest» company annually signs an agreement on socio-economic partnership "with the region, and the annual report for 2019 and the report on sustainable development are prepared in the format of a single document entitled «Creating the future together».

«OEMKINVEST LTD» demonstrates support and participates in the areas of socio-economic development, both in Stary Oskol and in Belgorod region as a whole (Table $1)$.
TABLE 1 - PROGRAMS OF INTERACTION BETWEEN THE CITY-FORMING ENTERPRISE AND THE REGION *

\begin{tabular}{|c|c|c|}
\hline $\begin{array}{c}\text { Investment program, } \\
\text { project implementation years }\end{array}$ & $\begin{array}{c}\text { Volum } \\
\text { e of } \\
\text { invest } \\
\text { ment }\end{array}$ & $\begin{array}{c}\text { Interacti } \\
\text { on with } \\
\text { the } \\
\text { authoriti } \\
\text { es }\end{array}$ \\
\hline \multicolumn{3}{|c|}{ Oskol Electrometallurgical Plant («Metallinvest» Holding) } \\
\hline $\begin{array}{l}\text { The social service of the «OEMKINVEST } \\
\text { LTD» plant issued SIF benefits. So, at the birth } \\
\text { of a child, employees were paid a lump sum } \\
\text { allowance in the amount of } 17 \text { thousand rubles }\end{array}$ & $\begin{array}{l}\text { more } \\
\text { than } 28 \\
\text { million } \\
\text { rubles. }\end{array}$ & $\begin{array}{l}\text { Corporat } \\
\text { e liability }\end{array}$ \\
\hline $\begin{array}{l}\text { Rehabilitation of workers of pre-retirement age. } \\
80 \text { sanatorium-resort trips to the sanatorium- } \\
\text { preventorium «Belogorye» and the sanatorium } \\
\text { named after Tsyurupy. }\end{array}$ & $\begin{array}{l}3,528 \\
\text { million } \\
\text { rubles. }\end{array}$ & $\begin{array}{l}\text { Corporat } \\
\text { e liability }\end{array}$ \\
\hline $\begin{array}{l}\text { Reconstruction of the city central embankment } \\
\text { of the Oskol River in the «Old Mill» quarter. } \\
2019\end{array}$ & $\begin{array}{l}100 \\
\text { million } \\
\text { rubles. }\end{array}$ & $\begin{array}{l}\text { Public } \\
\text { and } \\
\text { private } \\
\text { partnersh } \\
\text { ip }\end{array}$ \\
\hline $\begin{array}{l}\text { Improvement of material and technical } \\
\text { resources of schools and kindergartens of the } \\
\text { Stary Oskol urban district, National Research } \\
\text { University of Technology «MISiS», support of } \\
\text { needy families and children without parental } \\
\text { support, veterans, pensioners, graduate } \\
\text { students, students, teachers, preschool teachers, } \\
\text { cultural workers }\end{array}$ & $\begin{array}{l}1,3 \\
\text { billion } \\
\text { rubles. }\end{array}$ & $\begin{array}{l}\text { Corporat } \\
\text { e liability }\end{array}$ \\
\hline Corporate Volunteer Program «Respond!» & $\begin{array}{l}4 \\
\text { million } \\
\text { rubles. }\end{array}$ & $\begin{array}{l}\text { Corporat } \\
\text { e liability }\end{array}$ \\
\hline $\begin{array}{l}\text { Program of social partnership with the } \\
\text { Government of Belgorod region for 2016. In } \\
\text { particular, road construction }\end{array}$ & $\begin{array}{l}\text { exceed } \\
\text { ed } 1,7 \\
\text { billion } \\
\text { rubles/ } \\
1 \\
\text { billion } \\
\text { rubles }\end{array}$ & $\begin{array}{l}\text { Public } \\
\text { and } \\
\text { private } \\
\text { partnersh } \\
\text { ip }\end{array}$ \\
\hline $\begin{array}{l}\text { The program of social partnership with the } \\
\text { Government of the Belgorod Region for } 2020 \\
\text { for the development programs of Belgorod, } \\
\text { Gubkin and Stary Oskol (A. Nevsky Sports } \\
\text { Palace, reconstruction of the school stadium } \\
\text { No. 28) }\end{array}$ & $\begin{array}{l}1,6 \\
\text { billion } \\
\text { rubles. }\end{array}$ & $\begin{array}{l}\text { Public } \\
\text { and } \\
\text { private } \\
\text { partnersh } \\
\text { ip }\end{array}$ \\
\hline
\end{tabular}

* comp. aut. according to sources $[12,13,14,15,16]$

According to S.G. Piankova, for the socio-economic development of monoprofile cities, their «internal transformation» is necessary as a process of improving the socio-economic development of territories on the basis of the implementation of a system of independent decisions of the fate of the city aimed at financial, intellectual and industrial renewal of the city [1]. It is proposed as a source of selfdevelopment and independence of territories inter-municipal industrial cooperation [1]. The problems of inter-municipal cooperation are not new, they were dealt with by scientists [17], practitioners [18]. Since 2006, the Association "Council of Municipalities of the Belgorod Region" has been operating in the Belgorod Region with the aim of protecting the rights of municipalities, representing their common interests, as well as ensuring coordination of activities for the development of legal, organizational, financial, economic and territorial foundations of local self-government. Coordination is carried out on issues of a general nature. Inter-municipal agglomerations were also worked out, one of which was the Gubkinsky, Staro-Oskolsky, Chernyansky districts. The inclusion of the latter is due to the fact that a significant part of the residents of the Chernyansky district work at the «OEMKINVEST LTD», as well as the Chernyansky district is organically included in the food 
supply of the industrial mining and metallurgical complex. The legal and methodological mechanisms of agglomerations have not yet been worked out.

In general, the application of this form is due to insufficient own financial resources to solve the increased costs associated with the socio-economic development of the municipality; the existence of duplicate costs, the need to implement infrastructure investment projects that affect the interests of a number of municipalities; the need for «economies of scale» [18].

Inter-municipal economic cooperation requires an organizational and legal mechanism that allows you to coordinate interests, join efforts (including financial resources, material and other resources) and coordinate the actions of municipalities to solve issues of industrial development of territories, express and protect common interests [1], increase the professional competence of participants in the implementation of inter-municipal economic interactions $[19,20,21]$. There is a need for intermunicipal interaction with the establishment of horizontal and vertical links [22], cooperation within the framework of agglomerations and the inclusion of representatives of cityforming enterprises in the relevant councils.

Such joint activities will allow qualitative and quantitative assessment (calculation and measurement) of the connections and relationships arising in the socio-ecologicaleconomic system «region» and in its subsystem «regional industrial complex» $[23,24,25]$. It will also increase the attractiveness of the territory for investment and innovation.

\section{CONCLUSIONS}

Participating in the process of formation of innovation and investment attractiveness of the region, «OEMKINVEST LTD» uses both models of business and power cooperation and influence on regional development. But the greatest impact is shown by public-private partnership. Such a partnership brings maximum benefits to the region and citizens. The results are as follows: recreation areas are restored, funds are allocated for the development of the social infrastructure of the city and the region, the regional and local budgets are reduced under such agreements, and support is provided in the field of education. Thus, the presence of a city-forming enterprise in the Belgorod region does not make it vulnerable to the implementation of the innovation and investment process, and the metallurgical industry remains the foundation for the socio-economic development of the region.

At the same time, the participation of city-forming enterprises in the life of the region should be expanded by including inter-municipal economic cooperation in the mechanism. To this end, it is necessary to improve legislation on local self-government in order to ensure the synergistic effect of the interaction of business and government.

\section{REFERENCES}

[1] S. G. Piankova, "Socio-economic development of a monoprofile city based on the mechanism of internal self-transformation" // Economic revival of Russia, 2018, № 1 (55), pp. 91-104.

[2] On criteria for assigning municipalities of the Russian Federation to single-industry (single-industry towns) and categories of single-industry municipality of the Russian Federation (single-industry towns) depending on the risks of deterioration of their socio-economic situation: [Electronic resource]. Decree of the Government of the Russian Federation was adopted on July 29, 2014 No. 709. Access Mode: https://base.garant.ru/70707142/

[3] Passport of the priority project "Comprehensive development of single-industry towns" as amended by the protocol of November 30, 2016 No. 11 [Electronic resource]. Access mode: http://government.ru/news/25595

[4] A. A. Bogdanov, "Tectology Universal Organizational Science". Moscow: Finance, 2006, 496 p.

[5] M. B. Alekseeva, V. F. Bogachev, "Organizational aspects of social and economic system management: the theory and practice" // Problems of theory and management practice. 2020. N. 5. P. 6-14.

[6] Federal Law of 29.12.2014 "Of Territories of Advanced SocioEconomic Development in the Russian Federation" [Electronic Resource]. https://base.garant.ru/70831204

[7] Belgorod region in numbers. 2020. Short Statistical Compendium. 2020. Belgorod: Belgorod, 2020. - 244 p. [Electronic resource]. URL: https://belg.gks.ru/storage/mediabank/0107_2020.pdf

[8] A. E. Lapin, I. F Aliullov, "Foreign approaches to the organization of public-private partnership” // Management in Russia and abroad, 2015, № 2, pp. 64-70.

[9] A. V. Bazhenov, "Foreign experience in interaction between the state and production companies in the implementation of social projects" // Management in Russia and abroad, 2013, № 1, pp. 66-74.

[10] Information and analytical material on the results of socioeconomic development of the Belgorod region for 2019 [Electronic resource]. Access mode: https://belregion.ru/documents/

[11] "Metalloinvest" last year paid almost 20 billion rubles in taxes to the treasury of the Belgorod region [Electronic resource]. Access mode: https://abireg.ru/newsitem/74252/

[12] The main document of metallurgists [Electronic resource]. Access mode:https: //gmpr-belgorod.ru/?p=11847

[13] Chronicle of "OEMKINVEST" LTD[Electronic resource]. Access mode: http://deputatugarov.ru/news/letopis-oemk.html

[14] Methodology of Russian regions investment attractiveness rating [Electronic resource]. Access mode: https://raexa.ru/ratings/regions/2015/method

[15] "OEMKINVEST LTD" became the winner of the All-Russian competition of social efficiency [Electronic resource]. Access mode: https://stariyoskol.bezformata.com/listnews/vserossijskogo-konkursasotcialnoj/74580276/

[16] Corporate Volunteer Program "Respond!" [Electronic resource]. Access mode: https://www.metalloinvest.com/development/regionaldevelopment/otkliknis/

[17] Legal framework for inter-municipal cooperation. International Center for Social and Economic Research "Leontiev Center" [Electronic Resource] // Information collection of materials for the meeting of the Council on Local Self-Government under the Chairman of the State Duma of the Federal Assembly of the Russian Federation on the topic "Issues of development of inter-municipal economic cooperation". - M., 2009. URL: http://www.krags.ru/

[18] Regulation on the procedure for participation of the municipal district of the Ufa district of the Republic of Bashkortostan in organizations of inter-municipal cooperation [Electronic resource]. URL: http:/www.ufimadm.ru/Sovet/74_01.08.2013.doc

[19] J. Morgan, "10 principles of the future manager".2014. URL:http:thefutureorganization.com /10-principlesfuture-manager/

[20] J. Morgan, The future of work: attract new talent, build better leaders, and create a competitive organization. Hoboken, NJ: John Wiley \&Sons, Inc., 2014, $256 \mathrm{p}$.

[21] T. Wilson, "PFI: the Private Finance Initiative in the UK"// Infrastructure Journal, 1999, pp. 35.

[22] P. I. Burak, V. G. Rostanets, A. V. Torilin, "Institutes of coordination of processes of interregional and inter-municipal economic cooperation in the Russian Federation" // Bulletin of the Russian Academy of Natural Sciences, 2016, Tom. 16, № 4, pp. 58-62.

[23] A. A. Klamer, "Pragmatic View on values in Economics" // Journal of Economic Metodolog, 2003, June. Vol. 10, No. 2, pp. 54-59.

[24] Y. A. Doroshenko, A. A. Shevelev, I. V. Somina, "The private capital and investment financing" // World Applied Sciences Journal, 2013, №25 (1), pp. 124-132.

[25] Y. A. Doroshenko, L. A. Minaeva, Z. N. Avilova, I. V. Somina, , O. V. Leonova, "Socio-economic aspects of development of small innovative business in Russia" // Journal of Applied Engineering Science, 2015, №13 (4), pp. 293-298. 